\title{
Agricultural policy analysis with the AGMEMOD model: A new super model takes the stage?
}

[Maatalouspolitiikan analysointi AGMEMOD-mallilla: Uusi supermalli astuu näyttämölle?]

Csaba Jansik, Lauri Kettunen, Heikki Lehtonen \& Jyrki Niemi

MTT Taloustutkimus (MTTL), Luutnantintie 13, 00410 Helsinki

csaba.jansik@mtt.fi,

lauri.kettunen@kolumbus.fi,

heikki.lehtonen@mtt.fi.

jyrki.niemi@mtt.fi

\begin{abstract}
This paper presents an econometric, recursive dynamic, partial equilibrium multicommodity model for the Finnish agricultural sector developed within the AG-MEMOD modelling framework, a joint endeavour by several European research institutes. The objective of the AGMEMOD project is to build and validate an econometric model of the whole EU agricultural sector for projection and policy simulation purposes.

The building blocks of the AGMEMOD model are the national policy models. The specific aim of the Finnish modelling project was to build a country model on a common format so that it would link-up to provide an integrated model for the whole EU. The different commodities in the model are linked together through cross-price effects in supply and demand equations and the price transmission equations that link domestic prices with EU prices.

The responsiveness of the model to policy changes is demonstrated by comparing the results of different policy scenarios with that of the baseline scenario, i.e. continuation of the Agenda 2000 agricultural policy. The policy scenario examined in the paper is the CAP reform approved at the EU Agricultural Council in Luxembourg in 2003.

The main impacts of the CAP reform in Finland can be summarised as follows. Changes in crop sector are moderate. As regards to milk, the results indicate that the additional 10 percent cut in intervention price of butter beyond the Agenda 2000 agreement is estimated to reduce milk producer price by 4 percent and total milk production by 6 percent relative to the baseline.

The impact in the beef production is expected to be dominated by the developments on the dairy sector. Beef output will decline progressively to stand at around 6 percent below the baseline levels by 2010. Lower beef availability in the EU will trigger a rise in EU producer prices of some 6.5 percent and result a 3 percent higher producer price in Finland at the end of the simulation period compared to the baseline.

Though the broad patterns of reactions to agricultural policy reform are fairly predictable, the specific details are not so. In particular, when several geographic markets simultaneously change the policy, the impact of policy reform depends not only on domestic price elasticities, but also on the transmission of domestic production and consumption adjustments to the other countries' markets for that commodity, and the feedback effects between market prices and production and consumption decisions in the group of countries pursuing policy reform.

It is also highly promising that the findings are consistent with the other studies on the impacts of CAP reform on Finnish agriculture. Thus although there remains substantial scope for further research on the model (improving the estimation and specification of the sub-models), the model offers considerable potential for application even without additional development.
\end{abstract}

Key words: econometric models, Finland, commodity markets, policy analysis 


\section{Introduction}

Through the last decades, the use of economic models in relation to agricultural policy issues has increased substantially. Economic models serve as a means for better understanding the structure and parameters of the behavioural relationships underlying agricultural commodity markets.

This paper presents a multi-commodity model for the Finnish agricultural sector developed within the AG-MEMOD modelling framework, a joint endeavour by several European research institutes (Riordan, 2005). The objective of the AGMEMOD project is to build and validate an econometric model of the whole EU agricultural sector for projection and policy simulation purposes. The building blocks of the AGMEMOD model are the national policy models. Compatibility and performance of the country models is promoted by the common guidelines for model building in the AG-MEMOD partnership (Donnellan et al., 2001), which covers model validation with in-sample and post-sample performance of the models and their response to shocks.

The specific aim of the Finnish modelling project is to build the country model on a common format so that it, and its commodity sub-models, would link-up to provide an integrated model for the whole EU. Econometric sub-models are constructed for main agricultural commodities produced in Finland. The responsiveness of the model to policy changes is demonstrated by comparing the results of different policy scenarios with that of the baseline scenario. The policy scenario examined in this paper is the CAP reform approved at the EU Agricultural Council in Luxembourg in September 2003 (Council of the European Union, 2003). The most significant element in the 2003 CAP reform is the decoupling of most of the EU payments to arable crops and livestock from the production, combining these into a Single Farm Payment scheme.

\section{The structure of the Finnish model}

The Finnish AG-MEMOD model is an econometric, recursive dynamic, multi-product partial equilibrium commodity model. The specification of the model is inspired by the structure in Westhoff's (2001) EU GOLD (Grains, Oilseeds, Livestock and Dairy) model, which comprises separate models for the individual commodities. The commodities are linked together through crossprice effects in supply and demand equations and the price transmission equations that link domestic prices with international price. The commodity models describe acreage, animal stocks, yield levels, production, commodity stock building, food and feed demand, processing demand, imports and exports. Individual crop sector models are linked through the allocation of land, and crop and livestock sectors are linked through the use of feeds.

The range of commodities in the Finnish AG-MEMOD model spans soft wheat, barley, oats, rapeseed, vegetable oils and oil-based fodder meals, potatoes, sugar, beef, pork, poultry and dairy commodities (fluid milk, butter, cheese, skimmed milk powder and whole milk powder). The products contained in the model cover 58 percent of all agricultural land in Finland. There are some GOLD commodities which are not covered in the Finnish model due to climatic reasons. On the other hand, oats is included in the Finnish model, even though it is not a GOLD commodity (Jansik, Kettunen \& Niemi, 2003).

Figure 1 presents the general outline of a grain model, but it applies to all other products, if the production module is replaced by an appropriate supply module. For poultry, supply is a simple production function, whereas production module for milk and milk products is rather complicated as presented later on. Most equations are linear.

Determination of the key prices is the core of the whole model system. Given the world prices of commodities and the policy measures of the EU like intervention prices and WTO requirements the net export supply and the net export demand determine the equilibrium key price for each year. National prices are thereafter derived via price linkage equations. Country models are basically recursive by nature.

An essential requirement for the commodity submodels is that they have to close for each year. The sum of production, domestic utilisation, beginning and ending stocks, imports and exports has to be equal to zero i.e. one of the six components has to be a residual. A common rule was applied for all country models: the closing variable is the greater one of imports or exports. Since Finland is mostly exporting country of agricultural products, the closing variable is exports. The imports are determined by an equation of various factors and exports are then determined as an identity. 
Figure 1. AG-MEMOD Model Structure. Source: Chantreuil (2002)

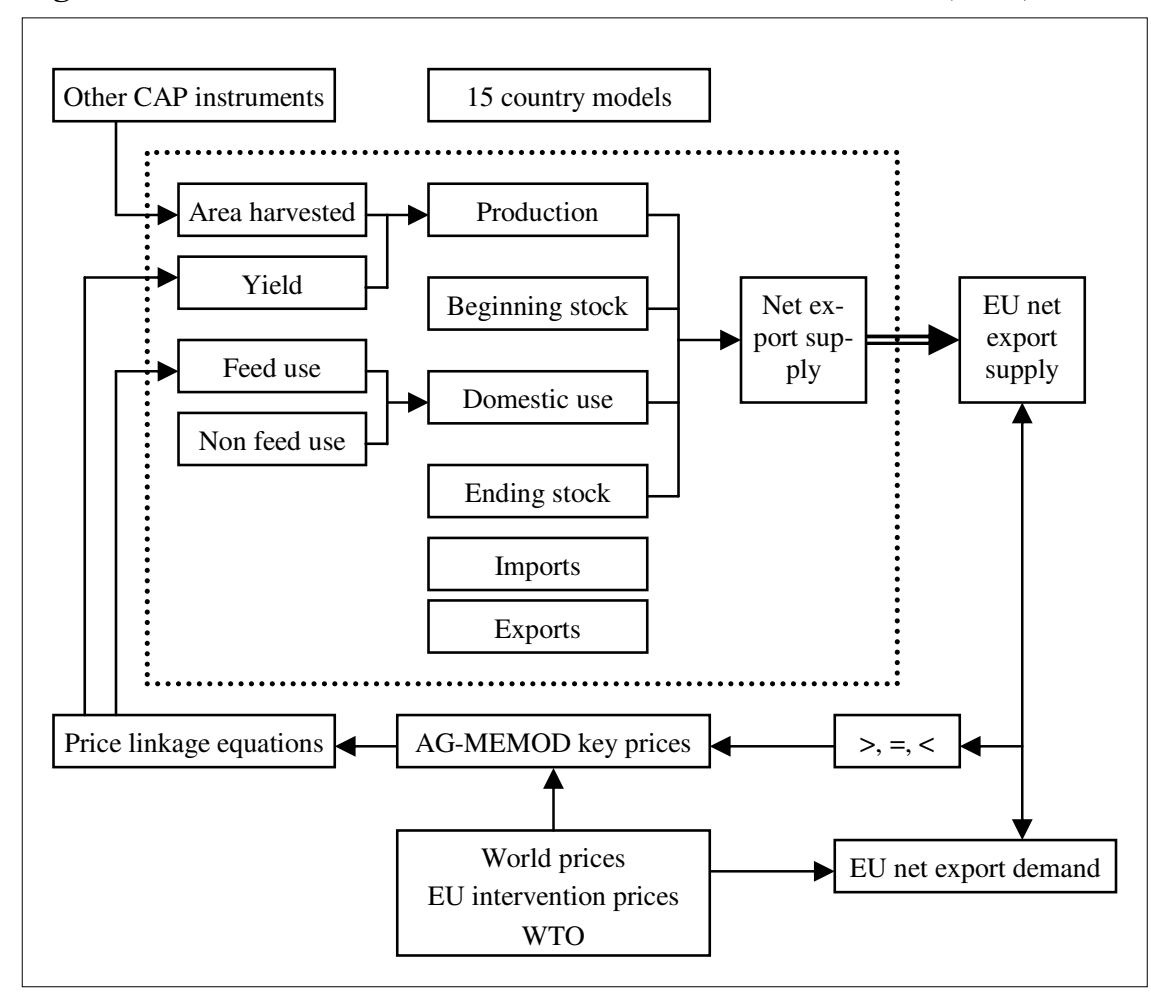

The nature of the economic relationships in the model - so far as is practicable - is based on time series econometric estimates of these relationships. The structural equations of the commodity models are generally estimated as single equations using ordinary least squares (OLS).

Most explanatory variables (in particular prices) are endogenous, determined by the model. The growth rates of GDP and population and exchange rates are exogenous. Costs are represented by cost indices. The cost index for the crops is assumed to

follow the GDP deflator. In animal production feed costs obviously depend on the grain prices, but other input prices depend on the factors outside the agriculture. Therefore, for each animal product a cost index is defined which depends on the prices of various grains and protein crops (barley, oats and rape seed in Finland) and the GDP deflator. The consumer price index is assumed to be the same as the GDP deflator in demand equations.

The fact that Finland joined the European Union in 1995 makes econometric estimations extremely difficult in all cases. The price linkage can be estimated only on the basis of EU membership period, because no direct relationship prevailed between the EU key prices and the Finnish prices before 1995. Similarly, trade and stock relations could be estimated only based on the EU membership years, since agricultural trade was strictly regulated by the state in the pre-accession period. As trade was liberalised in 1995, trade trends of the late 1990s should be handled with utmost care and caution, and their simple linear extrapolation to the next decade ought to be avoided. Various time periods were used for the estimations of the parameters of the demand and supply equations due to the changes in the prices and support systems when Finland joined the EU.

Various sensitivity tests were applied to check the applicability of the model. The elasticities are relatively small and shocks did not generate any projections which would not be acceptable. The model is not too sensitive even for big changes in values of variables.

\section{Model simulation: The effects of the Luxembourg Agreement \\ 'Business as usual' baseline scenario}

The baseline scenario, which was applied to assess the suitability of the model for policy purposes, corresponds to the continuation of the Agenda 2000 agricultural policy (agreed in Berlin 1999) over the medium term. The baseline simulation is a view of the world where policies remain unchanged. However, it is important to remember that the baseline scenario includes the reductions in intervention support prices and future increases in quota that were already politically agreed in Berlin 1999. The impact of EU enlargement has not been incorporated into the baseline.

The purpose of the baseline is not as a forecast of the future but to establish a yardstick against which policy simulations can be judged. The projections for the baseline are dependent on the assumptions of various macroeconomic indicators. The most important of these indicators are population, macroeconomic growth rates, inflation rates and key currency exchange rates such as the euro/US dollar (Binfield et al., 2003). First observation of the baseline is that prices are relatively stable (Table 1). 
Table 1. Main prices for the baseline scenario, $(€ / 100 \mathrm{~kg})$.

\begin{tabular}{|l|r|r|r|r|r|r|r|r|}
\hline & 2003 & 2004 & 2005 & 2006 & 2007 & 2008 & 2009 & 2010 \\
\hline Wheat price & 140.7 & 140.7 & 140.2 & 140.3 & 139.9 & 139.9 & 140.0 & 140.1 \\
\hline Barley price & 121.5 & 121.3 & 121.1 & 121.0 & 120.9 & 120.9 & 120.9 & 120.8 \\
\hline Oats price & 111.9 & 110.9 & 110.1 & 110.0 & 109.6 & 109.5 & 109.4 & 109.3 \\
\hline Beef price & 220.4 & 220.6 & 219.2 & 218.1 & 214.9 & 213.5 & 212.5 & 211.8 \\
\hline Pork price & 120.9 & 123.2 & 123.5 & 121.4 & 119.3 & 118.3 & 120.1 & 121.8 \\
\hline Poultry price & 109.0 & 108.7 & 108.6 & 108.4 & 108.2 & 108.1 & 108.0 & 107.9 \\
\hline Milk price & 30.1 & 30.2 & 29.6 & 29.1 & 28.4 & 28.4 & 28.5 & 28.6 \\
\hline
\end{tabular}

Stable prices generate also slightly falling area and production trends (Table 2). These results are in line with other studies and general expectations. Pork production is at a higher level at the moment than in the baseline scenario. It is a result of the national investment support which is not taken into account in the model. It is a temporary policy action, but it may cause a permanent rise in the production. It will be seen soon and the model may need to be calibrated to a new production level. Increasing costs press farm income downwards.

Table 2. Areas (000 ha) and production (000 tons) of main products and farm income (mill. euros) for baseline scenario

\begin{tabular}{|l|r|r|r|r|r|r|r|r|}
\hline & \multicolumn{1}{|c|}{2003} & \multicolumn{1}{|c|}{2004} & \multicolumn{1}{c|}{2005} & \multicolumn{1}{c|}{2006} & \multicolumn{1}{c|}{2007} & \multicolumn{1}{c|}{2008} & \multicolumn{1}{c|}{2009} & \multicolumn{1}{c|}{2010} \\
\hline Wheat area & 127.8 & 130.4 & 130.5 & 131.7 & 130.7 & 131.1 & 130.9 & 130.8 \\
\hline Barley area & 514.8 & 517.6 & 515.9 & 515.1 & 513.6 & 512.8 & 511.3 & 509.8 \\
\hline Oats area & 376.6 & 375.7 & 372.9 & 370.9 & 369.7 & 368.4 & 367.2 & 366.0 \\
\hline Beef production & 96.9 & 88.5 & 86.3 & 89.4 & 85.5 & 86.2 & 80.1 & 79.4 \\
\hline Pork production & 169.7 & 169.5 & 169.1 & 168.5 & 167.6 & 166.6 & 165.5 & 164.5 \\
\hline Broiler production & 73.6 & 76.6 & 79.5 & 82.5 & 85.4 & 88.3 & 91.2 & 94.0 \\
\hline Milk production & 2256.1 & 2282.9 & 2229.4 & 2189.1 & 2129.9 & 2148.8 & 2167.8 & 2186.0 \\
\hline Farm income & 1315.9 & 1276.9 & 1242.2 & 1203.5 & 1188.1 & 1148.3 & 1112.6 & 1061.3 \\
\hline
\end{tabular}

\section{CAP reform scenario}

The CAP reform scenario follows the Luxembourg Agreement approved at the Council of Agricultural Ministers in September 2003 (Council of the European Union, 2003). The most significant element in the reform is the de-coupling of most of the EU payments to arable crops and livestock from the production, combining these into a Single Farm Payment (SFP) scheme. Yet, the EU has given the Member States a number of options for implementing the reform. Part of the support may still be linked to production. There is a great deal of flexibility especially for the part of beef, but also for the part of cereals and milk. Thus, assumptions are made here regarding the de-coupling option. An option, in which 70 percent of the current CAP payments to arable crops and livestock are decoupled, is considered in the reform scenario.

In the AG-MEMOD model, so-called "modulation-decoupling" sheet calculates new supply inducing payment, which affects supply decisions. Since it is assumed that 30 percent of the current CAP payments will remain coupled, a coefficient 0.3 is chosen to adjust for change in supply inducing payment since reference period. It should be noted that some CAP payments are already treated as partially decoupled in pre-2003 reform baseline (Westhoff and Binfield, 2003).

The level of intervention prices and payments for the commodities changed in the reform scenario are set, as indicated in Table 3. The intervention price for butter is reduced 25 percent ( -7 percent in 2004, 2005, 2006, and -4 percent in 2007), which is 10 percent more than agreed in Agenda 2000. For skimmed milk powder (SMP) prices will be cut by 15 percent as agreed in Agenda 2000 (but in 5 percent steps over three years from 2004 to 2006). The price cuts are brought forward one year compared to the Agenda 2000 plan. Compensation payments to milk producers are fixed as follows: $€ 11.81 /$ tonne in $2004, € 23.65 /$ tonne in 2005 and $€ 35.50 /$ tonne from 2006 onwards.

Table 3. Policy variables changed in the Luxembourg Agreement Scenario

\begin{tabular}{|l|l|l|l|l|l|l|l|l|}
\hline Variable Name & 2003 & 2004 & 2005 & 2006 & 2007 & 2008 & 2009 & 2010 \\
\hline Butter intervention price & 328.2 & 328.2 & 305.2 & 282.4 & 259.5 & 246.4 & 246.4 & 246.4 \\
\hline SMP intervention price & 205.5 & 205.5 & 195.2 & 185.0 & 174.7 & 174.7 & 174.7 & 174.7 \\
\hline
\end{tabular}


The changes of the Luxembourg Agreement have an influence on the Finnish model both directly, through the changed policy variables, and indirectly, through the changed key reference prices. In the case of grains, the major driving force is the expected gross return, which includes the return of production plus subsidies. The basic assumption is that producers react to changes in expected gross return. As the expected gross return falls by 12 percent in the CAP reform scenario, this causes the 34 percent decrease of harvested area for all grain commodities.

Table 4. Changes in the prices of main product (in percent compared to the baseline scenario)

\begin{tabular}{|l|c|c|c|c|c|c|c|c|}
\hline & 2003 & 2004 & 2005 & 2006 & 2007 & 2008 & 2009 & 2010 \\
\hline Soft wheat & +00.00 & -00.00 & +00.08 & +00.08 & +00.08 & +00.08 & +00.08 & +00.08 \\
\hline Barley & +00.00 & +00.00 & +00.02 & +00.03 & +00.03 & +00.02 & +00.02 & +00.02 \\
\hline Oats & +00.00 & +00.00 & +00.09 & +00.12 & +00.11 & +00.10 & +00.09 & +00.09 \\
\hline Beef & +00.00 & +00.00 & +03.08 & +03.10 & +03.15 & +03.17 & +03.18 & +03.19 \\
\hline Pork & +00.00 & -00.00 & +00.06 & +00.06 & +00.06 & +00.07 & +00.07 & +00.07 \\
\hline Milk & -00.00 & +00.00 & -00.86 & -01.72 & -02.65 & -04.42 & -04.41 & -04.40 \\
\hline
\end{tabular}

Grain prices change very little in the CAP reform scenario. They tend to rise slightly, but the intensity of the changes remains at 0.08 percent for soft wheat, 0.02 percent for barley and around 0.1 percent for oats. This is a logical outcome of the projection. The decrease in grain production i.e. grain supply results in the slight increase of prices in a pursuit to equilibrium.

The harvested area and production is projected to decline slightly as a result of the decoupling. The reduction is smaller towards the end of the simulation period when markets have adjusted to the initial change. The area removed from grain cultivation is going to be shifted to set aside. The change would probably be greatest on sub-marginal soils and on farms with higher than average production costs, since harvesting and drying costs are high in Finland.

The impact of the 2003 CAP reform on the dairy sector is relatively modest because the baseline already incorporates Agenda 2000 decisions. Following the additional 10 percent cut in butter intervention price, Finnish butter price will be nearly 8 percent lower than in the baseline scenario by the end of the simulation period. This directly influences the changes in milk prices, which are 4 percent lower in 2010 compared to the baseline. Cheese prices do not change, while SMP prices are slightly ( 0.7 percent) higher than in the baseline.

Milk production is derived from the dairy cow stock and the production per cow, which both are lower in the CAP reform scenario, resulting 6 percent lower milk production figures compared to the baseline. Since fluid consumption does not change in the CAP reform scenario, the lower milk production directly affect the amount of milk available for processing. Milk for manufacturing use is found to decline by 8.6 percent by the end of the simulation period.

Table 5. Changes in the areas of grains, production of main animal products, and in farm income (in percent compared to the baseline scenario)

\begin{tabular}{|l|c|c|c|c|c|c|c|c|}
\hline & 2003 & 2004 & 2005 & 2006 & 2007 & 2008 & 2009 & 2010 \\
\hline Wheat area & +00.00 & -00.00 & -03.31 & -02.84 & -02.83 & -02.79 & -02.73 & -02.68 \\
\hline Barley area & +00.00 & +00.00 & -03.49 & -02.90 & -02.85 & -02.80 & -02.75 & -02.71 \\
\hline Oats area & -00.00 & +00.00 & -03.50 & -02.86 & -02.80 & -02.75 & -02.71 & -02.66 \\
\hline Beef production & -00.00 & +00.00 & -02.62 & +02.79 & -01.85 & -03.78 & -01.78 & -05.32 \\
\hline Pork production & -00.00 & -00.00 & +00.00 & +00.00 & +00.00 & +00.01 & +00.01 & +00.01 \\
\hline Milk production & -00.00 & -00.00 & -01.19 & -02.36 & -03.58 & -05.89 & -05.82 & -05.75 \\
\hline Farm income & +00.00 & +02.22 & +04.11 & +04.19 & +03.26 & +03.66 & +03.72 & +04.26 \\
\hline
\end{tabular}

The decrease in male bovine premium results in lower beef cow stock, but this effect has relatively little implication on meat production, since beef cow stock constitute only 10 percent of total cattle stocks. The cattle and beef sub-model is very strongly linked with the dairy sub-model. Since about 90 percent of slaughtered cattle come from dairy cows in Finland, the dairy stock decrease of 5 percent directly translates into a decline of calf production, and therefore lowers the cattle slaughter projections.

Beef prices are 3 percent higher in the Luxembourg Agreement Scenario than in the baseline. This price increase is caused by the changes in German key prices, which are over 6 percent higher 
than in the baseline. The higher prices are the results of lower beef availability in the EU market. However, following the decline in total cowherd - combined with the implementation of the decoupling scheme in the livestock sector - the cattle slaughter is projected to fall by 6 percent. As a consequence, beef and veal production will exhibit a 5 percent decline by 2010 in comparison with baseline levels.

Changes in farm income are caused only by the products included in the model. No changes in other sectors of agriculture are assumed. As a result of the CAP reform, farm income increases slightly (table 4). The reduction in the quantity of agricultural output is compensated by the resulting decrease in costs and by the higher level of direct support in the Luxembourg scenario since the decoupled support stays constant in spite of the decrease in the production. This result depends very much on the assumption of the volume of costs which should be kept in mind when the conclusions are made.

\section{Summary and conclusions}

The objective of this paper was to assess empirically the impacts of the 2003 reform of the Common Agricultural Policy (CAP) on the agri-food sector in Finland. The long term results of the CAP reform scenario from 2003 to 2010 were compared with the long term results of the baseline scenario, which corresponds to the continuation of the Agenda 2000 agricultural policy. To meet the objective, an econometric model for Finnish agriculture - built as a part of the AGMEMOD project - was utilised.

The most significant element in the CAP reform is the de-coupling of most of the EU payments to arable crops and livestock from the production, combining these into a Single Farm Payment scheme. Decoupling support from production will affect economic efficiency, structural development and supply of agricultural products in the entire agricultural sector.

However, land has to be kept in good farming condition in order to receive the farm payment. In practice, this would mean that land has to be cultivated or kept as set-aside land. Land abandonment or forest planting, for example, would not be possible.

Compared to a baseline scenario (i.e. Agenda 2000), the main impacts of the 2003 CAP reform in Finland can be summarised as follows:

- A reduction in the production level in several commodity sectors where production decisions are influenced by the level of support and by the coupled policy instruments in place. As a result, net exports of many agricultural products from Finland will decline. This concerns in particular wheat, barley, beef, butter and skim milk powder (SMP).

- A small increase in farm income as compared to the baseline. The reduction in the level of agricultural production is expected to be broadly compensated by the resulting price rises and the increase in the level of aids.

Changes in crop sector are found to be moderate. Decoupling improves the relative profitability of such crops and land uses whose CAP support has been lower than the support for cereals (silage grass and fallow) or which have previously received no CAP support at all (other grass area and other crops). In Finland, the central issue is how much of the cereals' area will become set-aside. The model indicates that, if 70 percent of the CAP support for arable crops will be decoupled from production, there will be an increase in the voluntary set-aside of approximately 15 percent, and a reduction in the area under cereals by around 3-4 percent.

As regards to milk, the results indicate that the additional 10 percent cut in intervention price of butter beyond the Agenda 2000 agreement will reduce the domestic price of butter by around 8 percent by the end of the simulation period. As a result, the production and exports of butter will be reduced by 9 percent and 12 percent, respectively. The reduction in butter production and increased demand for non fat solids in other dairy products will then reduce production of skim milk powder (SMP) by 19 percent and increase the SMP price slightly. These changes are estimated to reduce milk producer price by 4 percent and total milk production by 6 percent relative to the baseline.

The impact in the beef and veal production is expected to be dominated by the developments on the dairy sector. Changes in beef and veal production and cattle slaughter are a direct consequence of changes in total cattle stocks, which are made up of beef cow stocks and dairy cow stocks. As a result of CAP reform changes, beef and veal output will decline progressively to stand at around 6 percent below the baseline levels by 2010. Lower beef availability in the EU will trigger a rise in EU producer prices of some 6.5 percent and result a 3 percent higher producer price in Finland at the end of the simulation period compared to the baseline. 
After the simulation carried out to test the impacts of CAP reform on Finnish agro-food sector, the following questions naturally arise: To what extent do the results reflect reality and to what extent can they be ascribed to the characteristics of the analytical tool used? How useful is the chosen modelling approach as an analytical tool? What are the methodological or analytical lessons to be learned from the research?

It should be first acknowledged that the quantitative assessment of the impact of decoupling of direct payments is in general a difficult task. Thus caution is deemed necessary when analysing and interpreting the results from this quantitative analysis. Yet, the findings of the study are consistent with the other studies on the impacts of CAP reform on Finnish agriculture. Lehtonen (2004a,b), using a mathematical programming and technology diffusion approach, reported slightly larger reduction in overall dairy production, and a slightly smaller reduction in overall cereals production due to CAP reform and partially de-coupled CAP-payments, compared to simulations carried out in this study. The differences can be traced to the different modelling paradigms of the two studies. It is significant that the results of the two different models based on different paradigms are of the same direction. However, the magnitude of the production changes deserves more careful analysis. Robustness of the production changes on the model parameters could be tested.

The AG-MEMOD modelling framework provides a unified approach to the specification, estimation, and simulation of the national-level commodity markets. The Finnish model is well adapted for introduction into a framework of multi-country model of the whole EU. Such a comprehensive interactive framework of model is suitable for the study of the commodity, its responses to EU market changes, the international transmission of concurrent price changes, the impact of multilateral trade liberalisation, etc.

\section{References}

Binfield J., Donnellan T., Hanrahan K. \& Westhoff P. 2003. The Luxembourg CAP Reform Agreement: Implications for EU and Irish Agriculture, in proceedings of the conference: The Luxembourg CAP Reform Agreement: Analysis of the Impact on EU and Irish Agriculture, Teagasc Rural Economy Research Centre, pp. $1-69$.

Council of the European Union. 2003. CAP - Reform - Presidency Compromise (in agreement with the Commission). Brussels June 30, 2003.

Donnellan, T., Gracia, A., Jensen, J.D., \& Riordan, B. 2001. Guidelines for Model Building in the AGMEMOD Partnership. Online at www.tnet.teagasc.ie/AG-MEMOD/modellingag.htm

Donnellan, T., Hanrahan, K., McQuinn, K. and Riordan, B. 2002. Policy analysis with the AG-MEMOD Model: dealing with diversity in the EU Agri-Food Sector. Paper presented at the X EAAE Congress, Zaragoza, Spain, August 2002.

FAPRI (2003) World Agricultural Outlook 2003. Food and Agricultural Policy Resarch Institute, Iowa State University -University of Missouri-Columbia.

Hanrahan, K. 2001. The EU GOLD model 2.1: An introductory manual, Rural Economy Research Centre, Teagasc (http://www.tnet.teagasc.ie/agmemod).

Jansik, C., Kettunen, L. \& Niemi, J. 2003. The Finnish AG-MEMOD model: Applications and extensions for policy analysis, presented in the $7^{\text {th }}$ AG-MEMOD meeting, Athens, document no. M7:P13.

Lehtonen H. (2004a) Impact of de-coupling agricultural support on dairy investment and milk production volume in Finland. Acta agriculturae Scandinavica. Section C Food economics 1, 1, April 2004: 46-62.

Lehtonen, H. (ed.). (2004b) CAP-uudistus Suomen maataloudessa [Summary: CAP reform in Finnish agriculture]. MTT Working Papers 62: 140 p. Available at http://www.mtt.fi/mtts/pdf/mtts62.pdf

Riordan, B. 2005. Building Local Knowledge into EU Agri-food Projections: Experiences of a Fifth Framework Co-ordinator. EuroChoices 4(1).

Westhoff, P. (2001). The European Union Grain, Oilseed, Livestock and Dairy (EU GOLD) model, version 2.0, June 2000. Mimeo, FAPRI-UMC.

Westhoff, P. \& Binfield, J. (2003) Modelling the single farm payment', presented at the $7^{\text {th }}$ AG-MEMOD meeting, Athens, document no. M7:P29. 